Editorial

\title{
Genetic Research in Psychiatry: Update from the Society of Biological Psychiatry and the American Psychiatric Association, New York, May 1990
}

\author{
MA Crocq, F Duval, JP Macher \\ Centre Hospitalier Spécialisé, 68250 Rouffach, France
}

\begin{abstract}
Summary - A stimulating variety of papers on genetic and clinical research in psychiatry was discussed at the latest meeting of the American Psychiatric Association and the Society of Biological Psychiatry in May 1990 in New York. Conflicting results point out that extreme caution must be taken in interpreting linkage studies of psychiatric disorders. Difficulties stem from complex models on inheritance as well as the genetic heterogeneity of psychiatric disorders. Progress has been made in the approach to the regulation of receptor genes that have been implicated in the pathogenesis of psychiatric disorders. In some cases, gene regulation may be tissuedependent, as is suggested by the alternative splicing of $D_{2}$ receptor mRNA.
\end{abstract}

genetics / linkage / manic-depressive illness / Amish / Alzheimer's disease / schizophrenia / D 2 receptors / American Psychiatric Association / Society of Biological Psychiatry

Résumé - Recherche génétique en psychiatrie : mise à jour de la société américaine de psychiatry biologique et de l'association américaine de psychiatrie. Les congrès annuels de l'association américaine de psychiatrie et de la société américaine de psychiatrie biologique se sont tenus en mai 1990 à New York. Les recherches génétiques (études de liaison, études chez des jumeaux, biologie moléculaire des gènes des récepteurs impliqués dans les maladies mentales) ont occupé une place de choix. Les controverses se poursuivent autour des liaisons qui ont été rapportées antérieurement entre la psychose maniaco-dépressive, la schizophrénie, la maladie d'Alzheimer, et des marqueurs génétiques. Ces difficultés sont expliquées par des caractères en partie propres à la psychiatrie, tels que la complexité des modes de transmission génétique, l'hétérogénéité génétique et clinique des troubles, la difficulté de définir les phénotypes et la révélation tardive de certaines affections. La connaissance de la régulation des gènes impliqués dans les maladies mentales, notamment celle des gènes des récepteurs $D_{2}$, a aussi progressé notablement.

génétique / liaison / psychose maniaco-dépressive / Amish / maladie d'Alzheimer / schizophrénie / récepteurs $\mathrm{D}_{2}$ / association américaine de psychiatrie / société américaine de psychiatrie biologique

\section{Introduction}

Genetics has emerged as a highly fruitful area of research in psychiatry. It has contributed to the evolution of psychiatric nosology by indicating the etiologic heterogeneity of seemingly identical clinical conditions, and conversely by suggesting the common nature of apparently unrelated disorders.

Research strategies have varied over the years. They have relied on twin and adoption designs, familial segregation analyses and chromosomal studies. More recently, linkage analyses were made possible by the identification of polymorphic DNA fragments (restriction fragment length polymorphisms). Finally, today's molecular biology aims at identifying receptor genes and unravelling the regulation of their expression in the brain.

The sheer number of presentations at the latest annual meetings of the Society of Biological Psychiatry and the American Psychiatric Association in May 1990 in New York confirms that genetic research is an active field. No particular research strategy is outdated; each one is particularly suited to approaching certain questions. Regardless of the 
method used, the field of psychiatry has its own additional complexities, such as the difficulty of identifying phenotypes and cases.

\section{The fata morgana of linkage in manic-depressive illness}

Manic-depressive illness has been linked with the $X$ chromosome in independent samples in the USA, Belgium, Israel and Sardinia (Winokur et al, 1969; Mendlewicz et al, 1974; Baron et al, 1977; DelZompo, 1984). Linkage has been established notably with markers of the terminal fragment (28) of the long arm (q) of the X chromosome, including protan and deutan color blindness, and G6PD deficiency. A report by Egeland et al (1987) supported the existence of a gene conferring a strong predisposition to bipolar affective disorder linked to two loci on the short arm of chromosome 11 (11p15), the Harvey-ras-1 oncogene locus (HRAS1) and the insulin (INS) locus.

These studies had a noticeable impact on psychiatric thinking. They came as the logical molecular biology sequel to the adoption and twin studies of the previous decades and suggested that the identification of major susceptibility genes was just around the corner. However, linkage studies of psychiatric disorders have had notorious difficulties withstanding the trial of time. Controversies were revived by the re-analysis of the linkage between chromosome $11 \mathrm{p}$ loci and affective disorders in the Old Order Amish, presented at the APA meeting by Kelsoe (1990), in the wake of the article published in the 16 november 1989 issue of Nature. As far as is known, the chromosome 11 linkage has not been confirmed. The initial results of Egeland (1987) were based on restriction fragment length polymorphism (RFLP) studies at the HRAS-1 and INS loci in an 81-member pedigree (pedigree 110) with 6 ill probands from the Old Order Amish community in southeastern Pennsylvania. The Amish are an exceptional study environment because their community is extremely endogamous; they are a genetic isolate with minimal heterogeneity. Kelsoe presented results on an extended version of pedigree 110 . In addition to the 81 members of the original core pedigree, the new pedigree includes a 31 -member (8 affected) "right" extension and a smaller sixmember ( 2 affected) "left extension". Furthermore, two members of the core pedigree had their clinical status changed from unaffected to affected, and the genotyping of 10 unaffected individuals of the core pedigree was completed. With this new data, linkage to an affective disorder locus can be ex- cluded to 5 centimorgans for either HRAS1 or INS, in the total 120 -member pedigree and in the right extension alone. The new data, notably the presence of obligate recombinants in the core pedigree, has caused the lod score to drop from an original value of 4.08 to non-significance (at $\Theta=0$ in the two-point analysis between HRAS1 and bipolar affective disorder).

Besides the importance of diagnostic follow-up and of at least yearly visits of all the pedigree members, what particular or general conclusions can be drawn from the Amish study? First, some factors are related to the genetic paradigms that are pursued. It is important to bear in mind that linkage normally occurs in relation to a putative major susceptibility gene. Linkage is a strategy directed toward the search for a major Mendelian susceptibility locus, as opposed to additive "Galtonian" polygenic effects. Lack of replication in large populations casts doubt on the universal validity of a single-gene etiology.

Secondly, other factors such as the problems of genetic and clinical heterogeneity, and definition of penetrance and caseness, are closely dependent upon the particular psychiatric disorder that is studied. There are several possible interpretations of the nonreplication in the Amish group: either the initial report is simply not reproducible, or else there is genetic heterogeneity, which means that at least two different genes may be responsible for affective illness in the pedigree. It has been suggested by Egeland et al (1987) that several genes may be responsible for affective disorder within the Amish population itself, as several of the founding couples had mental illness among their first and second generation descendants.

Thirdly, questions arise concerning the exceptional genetic isolate that is studied and the generalization of linkage results beyond this highly inbred community. The Amish are descended from the Swiss anabaptists who appeared in the wake of the 16 th century religious reformation and later emigrated to southern Germany and Alsace to flee persecution. It would be interesting to investigate whether the chromosome 11 linkage could be replicated in the European parent population, which is considerably less inbred. It may be noted that the American Old Order Amish population is exceptionally inbred; genes flow out when subjects marry outside the community, but almost no genes flow in. The very closed American Amish community which is reported here might be expected to differ from its European forefathers by the combined result of two effects: the "founder effects" (only those who emigrated contributed to the new genetic pool) and 
the "genetic drift"' (the genetic pool of the new community evolved due to different fertility rates).

\section{Three paths to linkage}

In general, the search for linkage can be guided by three possible strategies (Gershon, 1990). The first strategy is to investigate linkage with "candidate genes", such as those involved in neurotransmission or neuroreceptors. However, this approach has so far failed to show a major susceptibility locus. For instance, linkage with the D2 receptor region (11q22-23) has been excluded in bipolar and schizophrenic pedigrees. Similarly, Lentes et al (1989) failed to show linkage with beta-1 (chromosome 10q24) and beta-2 (chromosome 5q31) adrenergic receptor genes in manic depressive pedigrees.

The second strategy is the exploration of markers in the region of a rare cytogenetic event found in rare pedigrees. This has been the case in schizophrenia where a report of a trisomy implicating the proximal long arm of chromosome 5 (5q11-13) inherited with schizophrenia (Basset et al, 1988) was followed by the finding that schizophrenia might be linked to a gene locus with a dominant susceptibility allele on chromosome $5 q$ in British and Icelandic families (Sherrington et al, 1988). However, negative findings were published at the same time by other researchers in a Swedish population (Kennedy et al, 1988). Kennedy et al (1990) presented additional results at the American Psychiatric Association meeting, and confirmed the absence of linkage to schizophrenia of the genes for tyrosine hydroxylase and the $\mathrm{D}_{2}$ receptor (chromosome 11); other areas of interest were also excluded for linkage in the same Swedish population: the genes for nerve growth factor, pro-opiomelanocortin, and the pseudoautosomal boundary (MIC2) of the sex chromosomes.

The third strategy is systematic mapping, and several papers based on this approach were presented in New York (Berrettini et al, 1990; Byerley et al, 1990; Polymeropoulos et al, 1990). Systematic mapping, leaving no region unexplored, is now possible, mainly because of the availability of polymorphic informative markers distributed throughout the genome and the ability to screen the whole genome in a less costly and more automatized manner. It had been estimated as early as $\mathbf{1 9 8 0}$ (Botstein) that 150 evenly spaced markers would ensure that no disease locus could be more than a $10 \%$ recombination distance from a marker locus. Preliminary results on systematic mapping of genes for manic-depressive disease were reported in May in New York. Berrettini et al (1990) studied a series of 20 bipolar pedigrees consisting of 375 informative subjects (160 bipolars, unipolars or schizoaffectives) under the assumption of a dominant gene, $1 \%$ frequency and $85 \%$ penetrance. Results with 20 DNA markers exclude linkage to 5p (short arm of chromosome 5), 5q11-q13, 5q32-34, 11p15 (region reported to contain the susceptibility gene for bipolar disease in the 1987 Old Order Amish study) and 11q22-23 (D2 receptor region). In the same line, Byerley et al (1990) conducted a systematic genomic mapping study using over 250 DNA markers and also reported absence of linkage on chromosome 5,11 and 19 in eight manic-depressive kindreds and eight schizophrenic families.

\section{Late onset of Alzheimer's Disease hinders linkage}

Several linkages have also been reported for $\mathrm{Al}$ zheimer's disease (AD). A number of authors examined chromosome 21 because Alzheimer-like neuropathology develops among patients with Down's syndrome. St George-Hyslop et al (1987) reported linkage of the rare disorder Familial Alzheimer Disease (FAD) to anonymous polymorphic DNA sequences mapping to the proximal long arm of chromosome 21. Positive LOD scores on 21q were also reported in FAD families in England by Goate et al (1989). However, some authors could not confirm these results; others even excluded linkage to the same markers by mapping other pedigrees (Pericak-Vance et al, 1988; Schellenberg et al, 1988). More recently, Roses et al (1990) reported positive LOD scores between AD and several markers on the long arm of chromosome 19 in an enlarged set of families. In this case too, genetic heterogeneity, ie multiple predisposing genes resulting in indistinguishable phenotypes, has been suggested to account for these discrepant or negative linkage results. In addition, clinical heterogeneity has been suggested. One form of the illness may be caused by a genetic defect on chromosome 21 and show early onset, typically in the fifth decade, while another more common form of the disorder may be a different genetic defect and show later onset, typically around the age of 60 .

However, proving genetic etiology and showing linkage meet with considerably more difficulties in AD than in manic-depressive illness or schizophrenia. It has been said that a large proportion of sporadic cases argue against the presence of genetic causes in most cases of AD. However, the discussion of results must take into account the particular characteristics of the disorder that is 
studied. Breitner et al (1988, 1989, 1990, and unpublished data) have emphasized that the very late onset of AD may preclude the occurrence of disease in many relatives whose earlier death has censored the expression of any inherited disease tendency. A characteristic of AD is age-dependent expression and variable age of onset. In the majority of cases, onset occurs in the eighth and ninth decade and therefore only one or two family members are affected. Such a limited number of affected subjects precludes the demonstration of linkage. It has been suggested that most AD cases may in fact be shown to have genetic causes. When appropriate allowance is made for censorship of disease tendency in relatives by other causes of death, the risk of Alzheimerlike dementia in first degree relatives of unselected clinically diagnosed $\mathrm{AD}$ probands increases with age and is about $50 \%$ over a lifespan of 90 years. One cannot help noticing that this figure is the risk expected in an autosomal dominant Mendelian illness. Because of the late onset of $\mathrm{AD}$, other methods such as twin studies may prove particularly useful. A pilot study in the National Academy of Sciences Registry of aging twin veterans was reported by Breitner et al (1990). The study of a sample of 442 pairs ( 884 subjects) suggests a $60 \%$ concordance rate for Alzheimer's disease in monozygotic twin pairs. This concordance rate will likely increase with ongoing longitudinal observation and exceeds prior estimates.

\section{New Approaches to $\mathrm{D}_{2}$ receptor genes}

Our understanding of neurotransmitter action has been refined by molecular biology studies of receptor genes expressed in the brain. This is particularly the case with $D_{2}$ receptors, which have been implicated in the pathogenesis of schizophrenia. Some data suggested an increased number of $D_{2}$ receptors in the brains of schizophrenics.

Two main types of dopamine receptors, $D_{1}$ and $\mathrm{D}_{2}$, have been identified by pharmacological studies. Bunzow et al (1988) have reported the cloning of a rat cDNA (complementary DNA copied from mRNA by the enzyme reverse transcriptase) with the expression characteristics of a $D_{2}$ receptor. Todd et al (1990) reported that the overall organization of this $\mathrm{D}_{2}$ gene is similar in rats, mice and man. It contains 8 exons (expressed DNA sequences), a very long first intron (intervening DNA sequence that is not translated in the polypeptide gene product), and spans at least 50 kilobases in the rat. In contrast to the genomic organization of most G-protein-coupled receptors, this $\mathrm{D}_{2}$ gene contains multiple introns. The interesting finding was that two forms of $\mathrm{D}_{2}$ mRNA were detected in various brain regions, and it has been suggested that the $D_{2}$ receptor gene identified by Bunzow gives rise to at least two major $D_{2}$ receptor mRNA subtypes (Todd et al, 1989, 1990). The two forms are generated by alternative splicing of an additional exon (exon 6) within intron 5; consequently the two resulting $\mathrm{D}_{2}$ proteins differ by the insertion of a 29 amino acid sequence. Splicing refers to the stage of mRNA processing whereby introns are removed. The relative proportion of the two alternative transcripts varies 25 -fold in different brain tissues. The exon 6 containing mRNA predominated in areas where $D_{2}$ receptor number is highest-basal ganglia, anterior pituitary, and olfactory bulb. These findings imply the presence of tissue-specific factors that control not only $\mathrm{D}_{2}$ gene transcription, but also alternative splicing of the pre-mRNA. Knowledge of the genetic organization of $D_{2}$ receptors is of obvious importance in schizophrenia and neuroleptic drug treatments.

New methods for the approach to neurons expressing $\mathrm{D}_{2}$ receptors were also discussed. In situ hybridization of $D_{2}$ receptor mRNA was reported in the primate brain by Meador-Woodruff et al (1990) after being reported in rats a short time ago (Meador-Woodruff et al, 1989). This technique complements studies using receptor autoradiography and PET; it reveals cell bodies and allows the study of earlier events in receptor synthesis. Regulation at the gene transcription or translation level might thus be explored.

\section{Conclusion}

No one doubts that genetics is a promising field in psychiatry. From pedigree studies to the molecular biology of receptor genes expressed in the brain, no particular approach is outdated. Each one is ideally suited toward investigating specific questions. Some results that were first presented a few years ago become the object of renewed controversy as recent findings emerge. Particular caution must be taken in interpreting the results of linkage studies until models of inheritance can be delineated with more clarity.

\section{Acknowledgments}

The authors are indebted to Ms Hein who kindly read the original manuscript. 


\section{References}

Berrettini WH, Detera-Wadleigh S, Goldin L, Martinez M, Hsieh WT, Gershon E (1990) Systematic genomic mapping of genes for manic-depressive disease: studies of chromosomes 5 and 11. Biol Psychiatry Suppl, 27, 9A, p 46A

Breitner JCS, Murphy EA, Silverman JM, Mohs RC, Davis KL (1988) Age-dependent expression of familial risk in Alzheimer's disease. Am J Epidemiol 128: 3, 536-548

Breitner JCS, Magruder-Habib KM (1989) Criteria for onset critically influence the estimation of familial risk in Alzheimer's disease. Genet Epidemiol 6, 663-669

Breitner JCS, Welsh K, Magruder-Habib K, Churchill C, Robinette CD, Folstein M, Priolo CC, Brandt J (1990) Pilot studies suggest $60 \%$ concordance for Alzheimer's disease in MZ twin pairs. Biol Psychiatry Suppl, 27, 9A, p 43A

Bunzow JR, Van Tol HHM, Grandy DK, Albert P, Salon J, Christie M, Machida CA, Neve KA, Civelli O (1988) Cloning and expression of a rat $\mathrm{D}_{2}$ dopamine receptor cDNA. Nature 336, 783-787

Byerley WF, Leppert M, Holik J, Lubbers AM, Jensen $\mathrm{S}$, White R (1990) Mapping genes for manic depression and schizophrenia. APA 143rd Annual Meeting. New Research Abstracts. NR206, p 126

Egeland JA, Gerhard DS, Pauls DL, Sussex JN, Kidd KK, Allen CR, Hostetter AM, Houseman DE (1987) Bipolar affective disorder linked to DNA markers on chromosome 11. Nature 325, 783-787

Gershon ES (1990) Genetics. In: Manic-Depressive Illness (Goodwin FK, Jamison KR, eds) Oxford University Press, pp 373-401

Goate AM, Owen MJ, James LA, Mullan MJ, Rossor MN, Haynes AR, Farrall M, Lai LYC, Roques P, Williamson R, Hardy J (1989) Predisposing locus for Alzheimer's disease on chromosome 21. Lancet i, 352-355

Gurling H (1990) Genetic linkage and psychiatric disease. Nature 344, 298

Haroutuninan V, Braider S, Snyder L, Sealfon S, Roberts JL, Davis KL (1990) Regulation of dopamine D2 receptor mRNA by chronic haloperidol treatment. Biol Psychiatry Suppl, 27, 9A, p 141A

Kelsoe JR, Ginns EI, Egeland JA, Gerhard DS, Goldstein AM, Bale SJ, Pauls DL, Long RT, Kidd KK, Conte G, Housman DE, Paul SM (1989) Re-evaluation of the linkage relationship between chromosome $11 \mathrm{p}$ loci and the gene for bipolar affective disorder in the Old Order Amish. Nature 342, 238-243

Kelsoe JR, Ginns EI, Egeland JA, Goldstein AM, Bale SJ, Pauls DL, Long RT, Conte G, Gerhard DS, Housman DE, Paul SM (1990) Bipolar Affective Disorder in the Old Order Amish In: Proceedings, APA 143rd Annual Meeting, 83B, p 244

Kennedy JL, Giuffra LA, Moises HW, Cavalli-Sforza LL, Pakstis AJ, Kidd JR, Castiglione CM, Sjogren B, Wetterberg L, Kidd KK (1988) Evidence against linkage of schizophrenia to markers on chromosome 5 in a northern Swedish pedigree. Nature 336, $167-170$
Kennedy JL, Giuffra L, Wetterberg L, Sjogren B, CavalliSforza LL, Moises HW, Gelernter JE, Pakstis AJ, Castiglione CM, Kidd KK, Kidd JR (1990) Genetic linkage studies of schizophrenia. In: Proceedings, APA 143rd Annual Meeting, 83D, p 244

Lentes KU, Höhe MR, Berrettini WH, Goldin LR, Gershon ES (1989) Eine Kopplungsanalyse beta-adrenerger Rezeptoren bei manisch-depressiver Krankheit mit molekulargenetischen Methoden. Biologische Psychiatrie 515-519

Meador-Woodruff JH, Mansour A, Bunzow JR, Van Tol HHM, Watson SJ, Civelli O (1989) Distribution of $\mathrm{D}_{2}$ receptor mRNA in rat brain. Proc Natl Acad Sci USA $86,7625-7628$

Meador-Woodruff JH, Mansour A, Healy DJ, Civelli O, Watson SJ (1990) Dopamine D2 receptor mRNA in brain. In: Procedings, APA 143rd Annual Meeting, 56E, p 206

Meador-Woodruff JH, Mansour A, Healy DJ, Watson SJ (1990) Distribution of dopamine D2 receptor mRNA in primate brain: an in-situ hybridization study. Biol Psychiatry Suppl 27, 9A, p 141A

Pericak-Vance MA, Yamaoka LH, Haynes CS, Speer MC, Haines JL, Gaskell PC, Hung WY, Clark CM, Heyman AL, Trofatter JA, Eisenmenger JP, Gilbert JR, Lee JE, Alberts MJ, Dawson DV, Bartlett RJ, Earl NL, Siddique T, Vance JM, Conneally PM, Roses AD (1988) Genetic linkage studies in Alzheimer's disease families. Exp Neurol 102, 271-279

Polymeropoulos MH, Xiao H, Delisi L, Weber LJ, Merril RC (1990) Use of (AC)N repeat polymorphisms in schizophrenia. APA 143rd Annual Meeting, New Research Abstracts. NR205, p 126

Robakis NK, Mohamadi M, Fu D, Refolo LM (1990) Cloning and characterization of two cDNA's encoding the human D2 receptor. Biol Psychiatry Suppl, 27, 9A, p 79A

Roses AD, Bebout J, Yamaoka L, Gaskell PC, Hung WY, Alberts MJ, Clark C, Welsh K, Earl N, Heyman A (1990) Linkage studies in familial Alzheimer's disease: Application of the affected pedigree member method. Neurology 40 (Suppl 1) 275

St George-Hyslop PH, Tanzi RE, Polinsky RJ (1987) The genetic defect causing familial Alzheimer's disease maps on chromosome 21. Science 235, 885-890

Schellenberg GD, Bird TD, Wijsman EM (1988) Absence of linkage of chromosome $21 \mathrm{q} 21$ markers to familial Alzheimer's disease. Science 241, 1507-1510

Sherrington R, Brynjolfsson J, Petursson H, Potter M, Dudleston K, Barraclough B, Wasmuth J, Dods J, Gurling H (1988). Localization of a susceptibility locus for schizophrenia on chromosome 5. Nature 336, $164-167$

Todd RD, Mack K, Gandelman K-Y, O’Malley KL (1990) Organization and expression of a dopamine D2 receptor gene. Biol Psychiatry Suppl, 27, 9A, p 140A

Welsch K, Breitner JCS, Magruder-Habib KM, Churchill CM, Robinette CD, Folstein MF (1990) Sixty percent concordance for Alzheimer's disease in monozygotic twin pairs. APA 143rd Annual Meeting, New Research Abstracts. NR201, p 124 